\title{
Children in Museums
}

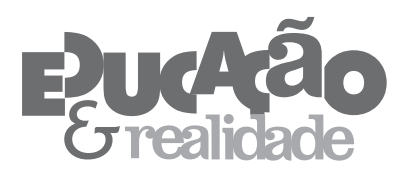

\author{
Cristina Carvalho' \\ Thamiris Lopes'
}

'Pontifícia UniversidadeCatólica do Rio deJaneiro(PUC-Rio), Rio deJaneiro/RJ-Brazil

\begin{abstract}
Children in Museums. This paper explores the relationship between culture, education and childhood based on studies that focus on the themes of museums and childhood, as well as on the observation of children visiting the Brazilian International Museum of Naïve Art, in Rio de Janeiro. The investigation aims to contribute to the dialogue between the fields of Education and Museology, highlighting children's right to access museums and receive quality attention on their premises. The results of the research show that museums have an enormous potential for developing moments of playful learning for young children, as long as we fill the gap in theoretical studies that elucidate the specificities of infancy in these spaces.
\end{abstract}

Keywords: Education. Childhood. Museums.

RESUMO - O Público Infantil nos Museus. Este texto apresenta reflexões acerca das relações entre cultura, educação e infância, a partir de estudos que se debruçaram sobre a temática da infância e dos museus, e do acompanhamento das visitas realizadas pelo público infantil ao Museu Internacional de Arte Naïf do Brasil, localizado na cidade do Rio de Janeiro. A investigação teve como objetivo contribuir para o diálogo entre os campos da Educação e da Museologia com vistas à garantia do direito de acesso e ao atendimento de qualidade das crianças pequenas a esses espaços. Com os resultados da pesquisa, foi aferido que os museus possuem um enorme potencial no desenvolvimento de momentos lúdicos de aprendizagem para o público infantil, desde que se diminua a lacuna nos estudos teóricos que elucidam as especificidades da infância nesses espaços.

Palavras-chave: Educação. Infância. Museus.

Educação \& Realidade, Porto Alegre, v. 41, n. 3, p. 911-929, July/Sept. 2016. 
The concept and view of childhood have changed throughout history, directly influencing public policies aimed at addressing the specificities of this age group. This research understands childhood as a stage of life in which subjects are constantly faced with apprehending distinct realities, absorbing and reformulating values and strategies that enable them to form their personal and social identity, and that children are subjects in their own right.

Sarmento and Barra (2002) argue that different instances and situations contribute to this process of identity formation, such as family, school relationships, community relationships, peer relationships and performed activities. Such interactions occur in various kinds of spaces that provide learning opportunities, whether formal, non-formal or informal, leading children to formulate opinions about the world, absorbing, building and producing cultural knowledge and practices in the social context in which they are inserted.

Given this specificity, we are faced with the need to create inclusion spaces for preschool children aimed at stimulating their development, considering their capacity for observation, cognition and creativity in all aspects, cultural ones included, which occurs more emphatically in places where non-formal education processes occur. In this sense, museums are privileged locations for non-formal education, capable of providing distinct dimensions of human experience, such as cognitive, affective and psychomotor. However, studies discussing the insertion of children in museums - especially aged 0 to 6 - are still scarce, as are museums offering special attention to this age group.

Cury (2007) emphasizes that the educational potential of museums lies in communicating a wide range of content in a dynamic and interactive way. We therefore believe emotion and imagination can become essential elements in educational practices in museums. Nonetheless, mere contemplation is not sufficient to ensure such experiences in museums. It is important that educational sectors implement actions that do not restrict the public, especially children, to contemplating objects, but foster enthusiasm for and critical appreciation of exposed works, based on a consistent work of mediation. As pointed out by Barbosa (2009), museums have much to contribute in terms of social and cultural mediation, and this is an area that needs consolidating in Brazil.

The Brazilian International Museum of Naïve Art (MIAN), located in Rio de Janeiro, is the most representative institution of this art genre in Brazil, and one that values educational interaction with its collection. In Finkelstein' view (2001), this atemporal art genre of human narratives irradiating joyfulness and colors resembles children's drawings. With adequate mediation, children can feel sufficiently attracted to develop an emotional relationship with the works of art, reflecting on various daily life themes. Owing to the specific attention it dedicates 
to children through educational initiatives, and being one of the only spaces in the city to receive children aged 0 to 6 , this institution was chosen, among so many of the city's museums, as the focus of the present research.

\section{Museums and Educational Proposals for Children in Museums}

It is widely acknowledged that one of the main ways in which children understand the world and produce culture is through play. According to Oliveira (2013), imagination developed in children's play does not repeat similar combination forms or isolated impressions gained from the many previous life experiences. Imagination used in play builds new series of thought, reasoning and perception. For Vigotski (2009, p. $22)$, "[...] the creative activity of imagination depends basically on the richness and variety of people's previous experience, since such experience constitutes the material on which fantasy is built".

Our feelings of fascination, strangeness, astonishment and curiosity when facing the novelties and discoveries afforded by these experiences are favorable conditions to arouse the imagination. These feelings accompany us throughout our whole life, but the greater intensity with which they occur in childhood is a specificity of children's perception of the world. Novelties that arouse strong and overwhelming emotions in children stimulate the imagination and enjoyment. Oliveira (2013) stresses that such fascination is not only triggered by contact with the latest technological inventions, but also by old objects, which are equally contents of discovery. Research by Po and Asensio (2006) on museum audiences reveals that children and youngsters do not so much demand attraction parks, but specific exhibition contents that meaningfully guide their expectations, initial motivation and learning possibilities.

Therefore, the encounter of children with museums can nurture this creative process through contact with objects and images that were once part of other childhoods. For Oliveira (2013), the greatest value museums can have for children, regardless of typology, is giving them the possibility to expand their imagination and, therefore, increasingly investigate the sense of exposed objects. In this perspective, the museum stimulates a feeling of admiration for things. Reddig and Leite (2007, p. 34) support this idea:

Interaction with different cultural expressions leads children to reflect, act, abstract senses and life experiences that enable subjects to construct meanings about what they do, how they do it, why they do it, what function it serves, besides developing the capacity to establish countless additional relations from that experience.

Educação \& Realidade, Porto Alegre, v. 41, n. 3, p. 911-929, July/Sept. 2016. 
However, providing such experiences for children has meant facing institutional obstacles in museum spaces. Michael Van-Praet (2003) argues that exhibitions are specific media that employ time, space and objects in a particular way. Analyzing such considerations about these media, and dialoguing with research by other authors on the relation between children and museums, we highlight below important points to be considered when devising educational activities for museum visits by this kind of audience.

\section{Time}

Time in a museum, a constitutive element of the learning process, is short, and should therefore be considered in all stages of museology, from mounting exhibitions to preparing educational activities for different audiences. For children, time for perception is also different. They may remain enthralled by something for quite a while, yet they also want and need to move around a lot with games and fun activities that prioritize motor skills.

Visiting museum exhibitions requires time for observation, since it is a constant exercise of concentration. This process involves the appropriation of senses and meanings not only in the rational dimension, but also in the sensitive dimension. Leite (2011) stresses the importance of offering this experience from infancy as a possibility of stimulating children, at an early age, to use the five senses and establish a distinct relation with the museum experience. Such experiences can enable them to create senses and connections capable of generating new meanings that will expand their repertoire, building a complex network of symmetries and contrasts.

Within this proposal, museums are understood as spaces of signification, fascination, production of critical knowledge, research, communication of nature and culture through exposed objects. The development of children's perception is enhanced by the possibility of seeing the objects - in their own time - and seeing themselves in the objects in a proposal of identity/alterity, which supports their self-perception as subjects of culture. These spaces afford the chance to apprehend history and culture through various means of play and interaction, configuring the presence of the past and present. Without overlooking the lightheartedness of the activities and alluding to children's inquisitive and participatory role, this corroborates the idea promoted by Cury (2007) that numerous aspects can be explored at exhibitions via distinct communication channels.

However, for children to admire works in ways that motivate them to observe and construct ideas and perceptions, museums must present proposals for mediation with discourses and expository layouts that also provide time and space for motor and emotional expression.

914 Educação \& Realidade, Porto Alegre, v. 41, n. 3, p. 911-929, July/Sept. 2016. 
Insisting on a mass of explanations and information about works and objects ends up reducing contact with the collection to its technical and historical dimensions, depriving children from moments of enjoyment. In this sense, educational proposals that allow children to have time and space to engross themselves in objects that spark their interest and rouse their imagination, without having their attention hurriedly diverted to other works in the exhibition by adults (teachers or mediators), is an important aspect of activities developed for this audience. And, inversely, stimulating observation, yet respecting and considering children's rhythm, which is often fast-tracked by their enthusiasm to explore an unknown environment, is also a factor to be considered when receiving children. Museums with outdoor grounds can offer children favorable conditions for physical exploration. Being on the move is an important element for children, yet using strategies that stimulate the fast association of ideas and the urge for free observation, avoiding the superficial consumption of the works on display, are further aspects to be observed when offering activities for children (Oliveira, 2103).

In her analysis of mediation processes used in art museums, Barbosa (2009) alerted that many programs are still based on fixed itineraries that direct the visitor's look exclusively to the works studied by mediators, neglecting the possibility of visitors, during observation, suggesting new itineraries with the mediator's help. In the author's opinion, " $[. .$.$] art, as a language that excites the senses, conveys mean-$ ings that no other type of language, such as discursive or scientific, is able to convey" (Barbosa, 2009, p. 21).

\section{Space}

The open space of a museum is also an integral factor of knowledge acquisition and in many ways distinct from school spaces. Regardless of age group or museum typology, visitors must be captivated by the exhibition throughout its entire itinerary, among themes and objects that produce meaning.

Pol and Asensio (2006) stress that one of the obstacles to receiving small children in museums is the persistent notion that visits by this age group pose problems in terms of security, collection conservation and tranquility. In an attempt to overcome this conventional view, the authors suggest conservation and museology professionals adopt a new posture, dialoguing with the newer generations in search of alternatives to change this kind of mentality.

In museum visits, there is an overarching concern to instruct children on what they cannot do or touch (Carvalho, 2103), and this type of reception can trigger a negative response. With so many behavior rules in museum spaces, such as no touching, no running, no eating, no drinking, no going behind protection ropes etc., Leite (2011) points out the need to think of the museum-child-play triad. 
Children in Museums

Preserving the security of collections is indisputable, but rather than highlighting what is forbidden, a solution could be to introduce areas with interpretation and communication resources that allow greater interaction, thus providing a more welcoming environment. Some museums have shown concern with this issue and attempted to develop specific activities for children, such as workshops, planned external areas, children autonomy, concerning both collections and mediatic proposals and also theatrical initiatives. It should be stressed, however, that the search for more dynamic and interactive mediation strategies can lead institutions to transform museum experiences into superficial activities, avoiding the exploration of themes and contents to suit the audience's interests, therefore reducing the institution's potential. As pointed out by Carvalho (2013, p. 311), small children deserve adequate attention and "[...] acknowledgment that they are capable of frequenting these spaces, that they have this right-as subjects and citizens - that they have specificities that must be respected".

The inadequacy of spaces for visits other than merely contemplative is a further aspect to be considered when receiving children. Stimulating contemplation is an important exercise in all stages of life, but in terms of the specificities of this age group, encouraging interaction and motor skills is even more relevant, since they enable numerous and multiple forms of expression. The lack of spaces for these kinds of activities (at the exhibition site or outside) is common in most institutions. This state of affairs does not contribute to changing the educational approaches adopted, not only for children, but for all kinds of audiences, since the focus of attention in museum spaces is mainly directed towards exhibition spaces and managing collections. Education professionals have to use their ingenuity to develop different activities using only outside premises and gardens, where weather conditions can hinder or prevent them completely.

A visit by preschool children can also be excessively noisy, disturbing museum staff and administrators, especially in those institutions following the traditional model of a historical and politically established order. Offering an experience of fascination and pleasure triggers communal excitement, which is not always expressed in silence. In fact, sharing emotions, doubt, discoveries and feelings of strangeness is a specificity of this kind of audience. Children want to observe objects up-close, discover and see what their colleagues have seen, and that produces buzz, laughter, feelings expressed in loud voices. Repressing such demonstrations means repressing children in museums.

The failure to adapt expository messages is another aspect that must be reviewed in museology. Pol and Asensio (2006) argue that it is rare to find any kind of content that does not fascinate children. Besides having infinite curiosity for things, children usually keep their own collections. Reflecting on childhood and evoking an untidy child, Benjamin (1995, p. 39) states:

916 Educação \& Realidade, Porto Alegre, v. 41, n. 3, p. 911-929, July/Sept. 2016. 
Each stone he finds, each flower he picks, and each butterfly he catches is already the start of a collection, and every single thing he owns makes up one great collection. Scarcely has he entered life than he is a hunter. 'To tidy up' would be to demolish an edifice full of prickly chestnuts that are spiky clubs, tinfoil that is hoarded silver, bricks that are coffins, cacti that are totem poles, and copper pennies that are shields.

The childhood habit of collecting reveals that material culture is greatly appreciated and valued at this stage. However, the messages conveyed by exhibitions must be attractive and easy to understand by all non-specialist audiences. Museums thus face the crucial challenge of valuing material culture through narratives that construct knowledge and values in an attractive way, instigating visitors to desire and pursue further information on the theme.

On the other hand, as stressed by Leite (2011), museum narratives must be planned to address multiplicity - in the sense of diversity - and foster a network system that welcomes differences. In this sense, it is important for museum institutions to acknowledge the existence of diverse childhoods in multiple spaces and times. Consequently, educational proposals for child audiences can be planned to address the non-homogenization of childhood, the evocation of plurality as a cultural prerogative and the perspective of museums as plural, welcoming, instigating and democratic spaces that provide pleasurable experiences and learning with multiple objects (and not only about those objects).

\section{Objects}

Objects are, therefore, also a fundamental part of the learning process in museums, inasmuch as they enable encounters that aim to construct meaning through observation. Learning to observe with a curious and sensitive eye that stimulates critical thinking about things is, consequently, a further element to be considered in activities developed for children.

Reddig and Leite (2007) point out that valuing material culture is part of children's world. Neighborhood exploration trips are commonly taken at different paces, faster or slower, in which individual objects are gathered, genuine treasures that spark children's curiosity and imagination. Sets of things are then hoarded, collections are created, invented, and values are assigned that justify the preservation and storage of these objects.

The authors argue that almost everything children do in open street spaces, in gardens, building, yards and surroundings is related to collecting, classifying, organizing and exhibiting private discoveries. However, to develop this outlook, children must have the opportunity to live this kind of interaction and experience. 
To understand the world and fulfill their role in society, children need to use their imagination, creativity and powers of observation, but also engage in play, games and role playing in various daily situations. Ludic activities and make-believe in museums help children to establish themselves as subjects and get to know themselves, others and the relations that pervade the social world. As stressed by Vigotski (2009, p. 14), "[...] the entire world of human culture, as distinct from the world of nature, all of this is the product of human imagination and of creation based on this imagination".

\title{
Educational Activities in Museums
}

Time, space and objects are therefore integral parts of the museum experience and must be considered in educational activities developed in museums. Ludic actions involving artistic and cultural languages can provide different experiences and favor personal experimentation and expression. In addition, such actions help to give new meaning to human and natural history in their complexity, making the invisible become visible. Therefore, museums are not only spaces of appropriation/enjoyment, but also of production/creation. When playing, children perceive and reframe culture through different languages that expand their sensitive view of the world.

Museums cannot be thus seen as rigid and homogenous structures in their educational initiatives, but as spaces enabling change, in continuous reformulation to trigger reflection capable of problematizing reality. In this sense, children can be stimulated to play with words, listen to stories, explore their expressiveness through artistic and cultural languages, drawing, painting, modeling, photographing, singing, dancing, role playing etc.

\begin{abstract}
We view curiosity as a vital element in the production of meaning, the opportunities to engage in play are perceived as moments that favor discovery; they are perceived as welcoming proposals for fascination. And perceiving child play as an expression of discovery and fascination means permanently inviting imagination to play a leading role - and if museums are places that spark curiosity, trigger the production of meaning, foster discovery and fascination, arouse the imagination... then we can say they are welcoming spaces that foster child play and fun! (Leite, 2011, p. 52).
\end{abstract}

In research carried out in museums worldwide, Pol and Asensio (2006) have detected that the programs they offer are often scarce, outdated, monotonous, and institutions do not restructure them over the exhibition period, especially in permanent expositions, failing to assure the preservation of quality and novelty in their educational activities. 
A common perception from an adult viewpoint is that children do not understand art or specific contents, which ends up limiting activities to recreation, amusement and play with no underlying cognitive aim. Some museums offer cultural entertainment as a strategy to attract the audience, yet with no significant value to expand knowledge about the contents on display. Likewise, some institutions organize superficial games that do not stimulate perception nor demand reflection, analysis and interpretation.

Oliveira (2013) emphasizes that an important practice to successfully plan educational activities for children, rarely employed by museums, is to listen to this kind of audience. To effectively grasp the needs and tastes of children, and enhance the quality of educational actions offered in these spaces, museums must listen to them. Carvalho and Porto (2013) analyzed the results of studies on issues related to how small children are received in museums, and pointed out that scarcely any of them considered listening to the children. Research on audiences generally ignores what children look at in a museum and how they act, for example, observe closely how they move around the space, the gestures, the assigned meanings, the whispers, the comments with peers and mediators, the fun, and even what does not attract their interest.

In terms of internal strategies, planning an adequate reception for children in museums requires studying the exhibition, its themes and the main concepts, and adapting the theoretical discourse to a language suitable for the age group, without depreciating the concepts addressed by the exhibition. Regarding external strategies, possible aspects to be considered are: creating flexible itineraries; prioritizing quality of interaction over quantity when selecting the works for the visit; creating adequate material for the interests of the age group; training staff teams frequently. However, as emphasized by Cazelli and Coimbra (2007), these strategies must be developed in tandem with a regular evaluation of the educational practices by education professionals during the exhibitions.

Also regarding external strategies, Leite (2011) points out that it is up to the museum team to create activities that enable children to associate what they see, touch, smell and feel with what they know to develop their thinking process. To this end, play and games are useful strategies. While younger children need experiences that are more tangible, the older ones strive to develop logical reasoning through games.

On the other hand, mediation between the individual and the collective provides experiences in which the individual can emerge as a field of possibility for group creation, instigating the value of individual opinion and collective criticism. Wallon (2007) affirms that the activities responsible for nurturing emotion happen in eminently social environments due to the effect they have on each other. In other words, reactions triggered by emotions in various environments function as a kind 
of fuel for individual and group expression. That is why an emotional mood prevails in events attended by large crowds, in situations where people lose their notion of individuality and emotions are shared with the social group - through games, dancing and other rites, people engage simultaneously in the same gestures and attitudes, surrendering to the same rhythm, the same emotion. In this way, individuals merge into groups through their most intimate and personal inclinations. The importance of this act in childhood lies in the enhanced possibilities of interaction with the environment, and these foster, through emotional enjoyment, access to the symbolic universe of culture.

We can therefore see that actions involving play, imagination and fascination in the development of educational activities for preschool children in museums generate numerous possibilities that are as yet poorly debated and attempted in museums. Institutional obstacles also exist, requiring constant evaluation of services in all sectors, and not only in those responsible for education actions.

\section{Preschool Audiences at MIAN}

Following the dialogue with authors who have studied childhood and the insertion of children in museums, we attempted to analyze whether the activities offered by MIAN to this age group included some of the aspects mentioned above. To this end, we present some of the reflections and observations about the visits of children to MIAN in 2013. We accompanied sixteen visits, previously booked by schools, to investigate the interactions between the different agents involved - children, mediators and teachers. It should be noted that the methodology employed also included informal interviews with MIAN staff.

Regarding the development of methodologies used in the different educational activities organized for preschool children visiting the institution, there was a concern with introducing various ludic activities in the itinerary. The aim of the museum team was to develop the children's imagination through games, music and fun activities to stimulate affective, motor and cognitive skills. An analysis of these methodologies reveals the inclusion of creative activities that are foreign to traditional museum patterns, such as creating a Carnival parade, activities involving music and sound, motor skills activities with dancing and statue games, among others.

Throughout much of history, and persisting down to our days, the notion that children could appropriate themselves of art to understand and grasp the complexity of expression was disregarded. Martins, Guerra and Picosque (1998) emphasize the role of mediation in this process of art apprehension by children: besides stimulating their cognitive observation, one must provide experiences to expose children to all senses, feelings and emotions, arousing their imagination and percep- 
tion. Among art museums, MIAN stands out for its work with children aged 0 to 6 .

Regarding play and imagination in the sphere of potential cultural experiences occurring in museum spaces, observations were made on the particularities of time, space, objects and educational activities in proposals to mediate the visits of preschool children to MIAN.

\section{Time to Play, Enjoy and Appreciate}

As explained above concerning the theoretical aspects of this research, time is a vital element in planning mediation work for children in museums. The itineraries must allow time for children to be fascinated by objects and use their imagination, and also be able to adapt to interests and desires emerging during the visit.

Despite following a set itinerary, the art educators at MIAN often adapted it according to the children's interest in a specific piece of work. Even when they couldn't stray from the schedule immediately, the requests were remembered later and satisfied. In the museum's basement, which housed an exhibit of international paintings, whenever a child mentioned having visited or heard of a specific place, the art educators would include a painting of that place in the itinerary. Throughout the visits we noted the recurring interventions by children (Ch) and the art educators' (AE) responses, such as:

Ch: Are we going to see that painting? AE: Yes, my friend, in a minute. We're looking at this one now. [...] Ch: What painting is that one, together with that whole bunch? AE: We'll get back to that one. One of you asked me who painted it. [...] Ch: My father has lived in Japan. AE: Then I'll show you a painting of Japan. [...] AE: Remember you told me you went to the CCBB? There's an artist who painted the CCBB, tell me what you recognize from there.

During the activities, a child often would stray from the group, showing greater curiosity for a painting that was not part of the itinerary or would be seen later. On such occasions, the art educators frequently said things like: "We'll soon look at that one... In a moment, my friend, because now we're looking at this one".

In this sense, when most of the group is interested in the work currently being shown and interacting with it, it is not convenient to interrupt the schedule. The intervention of teachers to satisfy the impending curiosity of a child who is interested in another piece of work is important, as are respecting the children's pace and exercising sensitive observation.

Exercising sensitive observation requires time for perception, which can vary greatly, involving longer periods to look at things that spark the children's interest and, likewise, agility to explore the remaining spaces and objects. The use of play and games that prioritize motor 
skills, observation and make-believe are good strategies to control time and, therefore, stimulate the children's curiosity.

However, there is seldom enough time available for children to visit the spaces in an autonomous way and create their own itineraries together with peers. Schools often arrive late and visiting times are too short for such proposals.

\section{Exploring and Discovering Museum Spaces}

It was observed that play is a constant element in mediation at MIAN, since, according to one of the staff, the institution acknowledges that children use play to understand the world and produce culture, and that it is a possible means of art apprehension.

Visits are held in the exhibition halls, where educational proposals are developed using different methodologies, such as stimulating the imagination, games, observation, interpretation, music, dancing, storytelling, and the use of technology to arouse the children's interest in the exposed works of naïve art. Naïve art concepts are introduced in these activities, and perception of different contents, such as far, close, large, small, colors, inside, out, nature traits, tourist sights, countries, cities, feelings, among other aspects, are addressed in a ludic way.

As emphasized at the beginning of this paper, imagination developed in children's play does not repeat similar combination forms or isolated impressions gained from the many previous life experiences, but builds new forms of thought, reasoning and perception. For Brougère (1995, p. 99-100), “[...] play is a mutation of meaning, of reality: things become something else. It is a space that lies outside ordinary life, obeying rules created by circumstance".

However, accompanying the children's visits to MIAN, it was possible to establish that even for those with prior experience in visiting museums, museums are viewed as places to keep old things, art, and not perceived also as playing spaces, as attested by the following statements gathered during our field work:

It's a place to see old things. [...] There are painting and drawings. [...] To see things that used to exist. [...] To see pictures. [...] It's to see things with the eyes. [...] It's to keep works of art and other things. [...] To see things that don't exist anymore. [...] To see sculptures. [...] To see how things are.

These were moments in which the art educators failed to explore the cognitive aspects of museums' roles as keepers of old things that are valued by humankind, thus stressing their raison d'etre as social institutions, i.e., important learning moments for the children were also lost, together with the opportunity to problematize how children signify museums. Analyzing the development of museums over history, socially seen as keepers of memory and cultural heritage, we know that dif- 
ferent groups within a same society were not granted rights to memory, heritage and access in an egalitarian and democratic way. To this day, the exercise of these rights to citizenship and belonging has to be conquered, asserted and reasserted in museum spaces.

Considering new ways of appropriation of these spaces by different audiences implies breaking the paradigms of routine security and quietness of more traditional museums. Searching for alternatives to foster a mentality shift, MIAN develops ludic activities in all stages of mediation, and has also created a Naïve Textures Hall, where children are allowed to interact with works and engage in more lively play, unrestricted, as attested by these statements by art educators gathered while accompanying children's visits:

Let's play a game? I'm going to play a song, and when it stops you have to show me the painting of the animal the song talks about. Meanwhile, we'll dance and mimic the sound and movement of these animals. [...] Let's touch the paintings? What do you think they are made of? Are they soft or rough? [...] Who can find a painting that is nice and warm? Who can find a cooler painting?

It should be noted that children must have the right to explore their curiosities in the different museum spaces without being restricted to a "specific place". In this sense, we identify a need for MIAN to reformulate some of its spaces to better cater for this age group.

Therefore, the optimization of external spaces, as well as expographic practices allowing higher level of attractiveness and adaptability to different educational proposals, can contribute for the accomplishment of wider and more ludic creation activities.

\section{Discovering the Art of Observing and Collecting Objects}

Objects, also considered an essential link in learning processes in museums, afford encounters that aim to construct meaning through observation. In this sense, MIAN attempts to develop a curious and sensitive sense of observation with regards to the things of the world depicted in the different naïve art themes. To this end, in the museum's itineraries, objects are viewed as elements that spark children's imagination and creativity, leading to activities of observation, play, games and make-believe.

Esthetically speaking, the works exposed at MIAN are normally attractive to children, with an intense use of color and the depiction of popular themes, and the museum exploits this facet to stimulate in children a sense of appropriation towards art and the collecting activity characteristic of museums and children. The children, like the founder of the museum that collected naïve art, declared having their private collections: "I have a Lego collection. [...] I collect toy cars. [...] I have a boat collection. [...] Ball collection”. 
Besides the sensitive observation of exposed objects, it is equally important to stimulate the various ways in which children can express themselves as collective and participative individuals, capable of expressing their desires, emotions, thoughts and opinions in the context in which they are inserted. In the mediation work observed, dialogue is the foundation for children to express themselves regarding the observed objects:

Does this Indian girl fit inside this house? [...] Have you ever been to a party like this one in the painting? [...] Point out a place in the picture you have been to. [...] Let's look at the painting and see if there's anything we want to say about it. [...] Why do you think so? [...] Can someone help me discover what these three little dots in the painting are? I've never figured out what they are. [...] Can the man really be taller than the building? [...] Who thinks it's something different from what your friend said? [...] What is happening? How do think the artist managed to do that? [...] Do you know the name of the music equipment painted there? [...] These pictures were painted by an artist with a difficult name, can you repeat it with me: Henri Rosseau? [...] Let's count together how many pictures here were painted by the same artist? [...] Which musical instruments shown in this painting do you know? Let's organize a museum marching band? What do we need in a band?

The children, in turn, showed they are capable of criticizing and checking the authenticity of the places they know depicted in the naïve paintings: "But the Statue of Liberty is not like that, it's green. [...] I've visited that fountain with my grandmother, but it's not really like that. [...] But the cars are not that color. [...] The buildings are gray".

Wallon (2007) considers this cognitive work of art interpretation done by children as characteristic of the "personalism stage," common to the 3 to 6 age group, in which the exercise of the search for language provides the representation of things that don't exist or could exist, supplying children with ways to express, establish and analyze what is present and absent. According to the author, in this phase children learn to superpose the world of signs on moments experienced in life.

Therefore, adequate mediation work carried out in museums, stimulated by object interpretation, also contributes to cognitive development in children.

\section{Educational Activities: playing and learning moments}

Based on the museum elements of time, space and objects examined above, institutions should plan educational activities based on the objectives they aim to reach in their mediation work with children.

For Martins, Picosque and Guerra (1998), mediation implies stimulating the subject's possibilities of enjoyment as a whole: not only fostering cognitive observation, but also providing experiences that allow space for senses, feelings and emotions, sparking the imagination and 
perception. Proposing activities to interpret works of art means mediating, providing access, instigating greater sensitive contact, expanding the possibilities of producing meaning in a process of internal construction that is not limited to trivial question-and-answer activities. In this sense, the mediation work at MIAN stands out for its quest to stimulate make-believe, imagination, storytelling and play:

Let's look at this painting: can that boat pass under the bridge? [...] In this museum painting we're looking at, we can imagine that we are painted in it and entering here! [...] Let's imagine ourselves dancing in the painting. [...] If you could name this painting, what would it be? [...] How long do you think it took to paint this picture? [...] Let's invent a name for this mixture of animals? [...] Let's imagine he picked these flowers. [...] I always imagine that this song was being played in this picture, will you sing it with me? [...] What kind of sound does this thing in the picture make? [...] What do you find hard to believe in the painting, and why?

The literature about museums stresses the dearth of educational activities for preschool children. However, repetition and lack of reformulation are not recurrent problems at MIAN. The institution offers a diversity of proposals for activities and, at each exposition, new activities are devised to ensure dynamism and adjust action to the proposals.

Generally speaking, information was not simply passed on to the children, and the art educators sought to ask questions and enquiries, thus allowing the children to reflect and formulate opinions about the works before them:

What kind of music could be playing? [...] Do you think this music (the art educator plays samba on the tablet) could be playing in this place? Do think that Galvão, the naïve artist that painted this picture of a match at Maracanã Stadium, was rooting for which team, Flamengo or Fluminense? Why? [...] This world is rather crazy, why are all the houses flying, and the trees also? [...] This painting shows something that Vinícus de Moraes really liked, who can discover what it is? [...] Who wants to tell a story about what's happening in this painting? [...] We can imagine the stories these paintings are telling us. [...] Who wants to tell a different story from their friend's? [...] Let's sit down in front of this picture so I can tell you a really nice story. [...] Let's play a game? I'm going to give you the cards of this game called LYNX and you have to find the card images on this huge board. [...] I'm going to play a song and you have to imitate the animal. [...] Let's play statues?

Thanks to the mediation work that constantly encouraged observation and dialogue, children visiting the Rio de Janeiro Nä̈ve exhibition showed they were capable of not only recognizing various of the city's tourist sights and neighborhoods where their homes and schools ${ }^{1}$ were located, but also remember and verbally express, seeking for a logical sequence to communicate with peers and the art educator, situations they had experienced and recalled by observing the naïve painting of the place: "I've been there with my father. [...] This is the place where they have the Carnival parade (sambadrome). [...] I live here. [...] This is 
Urca, where our school is. [...] I went there yesterday with my father to watch the game (Maracanã Stadium).

The museum team also sought to exploit the children's repertoire of impressions and perceptions experienced in the museum to foster the creation of senses and connections capable of producing new meanings, allowing them to further expand their knowledge.

\begin{abstract}
All paintings here have small labels at the bottom informing the name of the artist and painting and when it was painted. [...] Do you think these pictures were painted by the same artist? [...] Do you think this painting has the same style as the other? It's because they were painted by different people, some artists paint large people, others paint really tiny people. [...] The naïve artist doesn't go to art school, but he practices, practices, practices and discovers his own style of painting. [...] Do you think these paintings with similar colors were painted by the same person?
\end{abstract}

Concerning educational activities proposed for children in museum spaces, it is important to develop dynamic and interactive strategies to cater for this kind of audience; however, it is equally import to avoid transforming mediation into superficial activities, failing to explore the specific themes and contents of the exhibition.

\title{
The International Museum of Naïve Art as a Possibility for Receiving Children
}

From the observations and informal interviews with MIAN staff, it was observed that the museum's mediation work values children's answers, expressed in various ways, which gradually acquire meaning in relation to the contents apprehended throughout the visit. Aiming to provide better attention to children in museums through an educational proposal that addresses their specificities, it is possible to conclude that, generally speaking, MIAN has contributed to the debate on child inclusion in museums. However, ideally this should not be an isolated action, developed for a single space, or devised exclusively by the educational sectors of institutions. A research line that addresses different kinds of audiences in the preparation of all stages of the museum process, especially concerning language and layout, emerges as a relevant aspect in museum studies.

Obstacles to offering quality attentionto children are recurrent even at MIAN, such as: lack of security in the building, which prevents children from accessing the museum's third floor (mezzanine); children's difficulty to use the naïve electronic game, due to its inadequate height; occasional demonstration of a conception of childhood at odds with the institution's proposal; welcoming circles with behavior restrictions at the beginning of each visit; poor use of outside spaces; and lack of professionals. These and other aspects are recurrent in other museums that have not yet considered the inclusion and accessibility of

926 Educação \& Realidade, Porto Alegre, v. 41, n. 3, p. 911-929, July/Sept. 2016. 
different audiences in their internal and external spaces, and, on the other hand, the lack of research addressing child audiences leads to the implementation of palliative measures. For Pol and Asensio (2006), the excessive importance still given today to exhibition and administrative spaces compared to spaces for educational services persists as one of the main problems when considering the offer of activities to children.

We did not identify any evaluation process of the activities carried out at MIAN, and the constant exercise of evaluating and reformulating practices can result in methodologies that increasingly explore the use of senses by this age group in museum spaces. This perspective once again highlights the importance of museums adopting evaluation practices of mediation work to support audience research capable of specifying aspects that trigger feelings of curiosity, fascination and strangeness in children visiting the institution. We believe that an evaluative practice focused on the children and looking for different ways to listen to this audience is a fruitful approach to inserting children in museum institutions, guiding and (re)formulating educational action.

At the end of the field work carried out in the museum, observing directly the work of mediation with preschool children, in light of the theoretical studies provided throughout the research, it was possible to perceive that museums have great potential to afford playful moments of significant learning for children.

To this end, it is necessary to plan educational proposals for this age group that draw on academic studies on the specificities of child development. Concerning this aspect, Martins, Picosque and Guerra (1998) affirm that is essential to consider children in their totality, so that, during their development, perception can function as a blend of thought and feeling, which allows them to signify the world, since being alert to the world is a constant awakening. Therefore, proposing learning situations for this age group implies fostering situations of strangeness, perception, reflection and production.

We acknowledge and stress that there is a long way ahead: generally speaking, institutions do not consider children while planning activities and surveying audiences; and, with regards to researchers, this is an area that has attracted little to no interest. Within this perspective, we hope this study may contribute to stimulate this kind of evaluative practice, not only at MIAN, but also in other museum institutions, and also serve as a subject of future investigations.

Received on December 12, 2014

Approved on November 29, 2015

Translation from Portuguese: Pedro Barros Translation Review: Ananyr Porto Fajardo 


\section{Note}

1 It is important to stress that the mediated visits observed were all by private preschool institutions. During the study period MIAN received very few request for visits by public schools, which prevented a more in-depth analysis in this aspect.

\section{References}

BARBOSA, Ana Mae. Mediação Cultural é Social. In: BARBOSA, Ana Mae; COUTINHO, Rejane (Org.). Arte/Educação como Mediação Cultural e Social. São Paulo: Editora UNESP, 2009. P. 13-22.

BENJAMIN, Walter. Obras Escolhidas II: rua de mão única. 5. ed. São Paulo: Brasiliense, 1995.

BROUGÈRE, Gilles. Brinquedo e Cultura. São Paulo: Cortez, 1995.

CARVALHO, Cristina. Criança Menorzinha... Ninguém Merece: políticas de infância em espaços culturais. In: KRAMER, Sonia; ROCHA, Eloisa (Org.). Educação Infantil: enfoques em diálogo. Campinas: Papirus, 2013. P. 295-312.

CARVALHO, Cristina; PORTO, Cristina. Crianças e Adultos em Museus e Centros Culturais. In: KRAMER, Sonia; NUNES, Fernanda; CARVALHO, Cristina. Educação Infantil: formação e responsabilidade. Campinas: Papirus, 2013. P. 133-150.

CAZELLI, Sibele; COIMBRA, Coimbra. Avaliar as Ações Educativas em Museus: como, para quê e por quê? In: ENCONTRO NACIONAL DA REM/RJ, 2010, Fundação Casa de Rui Barbosa, Rio de Janeiro. Anais... Rio de Janeiro: Fundação Casa de Rui Barbosa, 2010. P. 165-187.

CURY, Marilia Xavier. Exposição: uma linguagem densa, uma linguagem engenhosa. In: VALENTE, Maria Esther (Org.). Museus de Ciência e Tecnologia. Rio de Janeiro: MAST, 2007. P. 69-76.

FINKELSTEIN, Lucien. Brasil Naïf: Arte Naïf: testemunho e patrimônio da humanidade. Rio de Janeiro: Novas Direções, 2001.

LEITE, Maria Isabel. Museu, Crianças e Brincadeira: Combinação possível? In: ALMEIDA, Marcos Teodorico. O Brincar e a Brinquedoteca: positividades e experiências. Fortaleza: Premius, 2011. P. 41-55.

MARTINS, Miriam Celeste; PICOSQUE, Gisa; GUERRA, Maria Terezinha. Didática do Ensino de Arte: a língua do mundo: poetizar, fruir e conhecer arte. São Paulo: FTD, 1998.

OLIVEIRA, Alessandra. Museu: um lugar para a imaginação e a educação das crianças pequenas. In: KRAMER, Sonia; ROCHA, Eloisa. Educação Infantil: enfoques em diálogo. Campinas: Papirus, 2013. P. 313-330.

POL, Elena; ASENSIO, Mikel. La Historia Interminable: una visión crítica sobre la Gestión de Audiencias Infantiles en Museos. MUS-A. Revista de los Museos de Andalucía, Andalucía, v. 4, p. 11-20, 2006.

REDDIG, Amalhene; LEITE, Maria Isabel. O Lugar da Infância nos Museus. Revista Musas, Brasília, p. 32-41, v. 3, 2007.

SARMENTO, Manuel Jacinto; BARRA, Sandra. Os Saberes das Crianças e as Interacções na Rede. 2002. Disponível em: <http://www.ced.ufsc. br/ zeroseis/lart14.doc>. Acesso em: 30 set. 2014.

928 Educação \& Realidade, Porto Alegre, v. 41, n. 3, p. 911-929, July/Sept. 2016. 
VAN-PRAET, Michel. A Educação no Museu, Divulgar 'Saberes Verdadeiros' com 'Coisas Falsas'? In: GOUVÊA, Guaracira; MARANDINO, Martha; LEAL, Maria Cristina (Org.). Educação e Museu: a construção social do caráter educativo dos museus de ciência. Rio de Janeiro: Access Editora, 2003. P. 47-62.

VIGOTSKI, Lev. Imaginação e Criação na Infância. São Paulo: Ed. Ática, 2009.

WALLON, Henri. A Evolução Psicológica da Criança. Tradução de Zoia Prestes. São Paulo: Martins Fontes, 2007.

Cristina Carvalho has a Doctor of Education degree and is a professor of the Graduate Program in Education at PUC-Rio and coordinator of the Undergraduate Course in Pedagogy and the Specialization Course in Preschool Education (PUC-Rio). She coordinates the Research Group in Education, Museum, Culture and Childhood (GEMENCI).

E-mail: cristinacarvalho@puc-rio.br

Thamiris Lopes is a doctoral candidate in Education and has a master's degree in Museology and Heritage (UNIRIO) and a bachelor's degree in Pedagogy (UERJ). She is a member of the Research Group in Education, Museum, Culture and Childhood (GEMENCI/PUC). She does research in the areas of childhood, museums and formal and non-formal education.

E-mail: thamiris_bl@hotmail.com 